\title{
Hexapods as a source of nutritive and biologically active agents
}

O. Metlytska,

doctor of agricultural sciences, Institute of Animal Breeding and Genetics n.a. M.V.Zubets NAAS

S. Melnychuk, academician of NAAS, doctor of biology sciences, Taras Shevchenko National University of Kyiv V. Spyrydonov, doctor of agricultural sciences, Institute of Veterinary Medicine of NAAS

The purpose. To analyze results of domestic and foreign probes of last years concerning opportunity of use of hexapods as a source of the balanced nutrients for branch of animal husbandry, biologically active ingredients for needs of medicine and veterinary science. Methods. Analytical, theoretical generalization. Results. Assay values of domestic and foreign sources concerning opportunity of growing hexapods of the certain kinds on industrial basis are brought at reclamation of waste materials of food-processing industry and stock-rearing farms for deriving low-cost nutritive ingredients of feedstuff of agricultural animals. Perspectives of industrial entomology are specified at solution of problem of human and veterinary medicine. Conclusions. Building new economic sector of industrial entomology for deriving articles of food and feedstuff requires development of versatile intra- and interdisciplinary approaches for provision of efficient cooperation between public authorities, specialists of different industries and sciences.

Key words: hexapods, nutrients, conversion of feedstuff, protein, organic waste materials, chitozan, antimicrobial peptides.

Insects are the most common animal fauna class. In this biodiversity, there is a huge potential for a wide range of uses for the needs of mankind. Honey bees (Apis mellifera) have long been used to produce honey, get wax, perg, pollen, royal jelly, drone's homogenate and apitoxin. A dangerous pest for bee families - the wax moth (Galleria mellonella), was almost a panacea for a number of serious human diseases - tuberculosis, arthrosis, cancer, immunodeficiency states and autoimmune disorders [1]. Silkworm (Bombyx mori) is a source of natural raw silk, and its most powerful industrial production is located in the People's Republic of China, where more than 1 million working places are involved. This technological livestock industry is the main source of income for 700,000 families in India and over 20,000 in Thailand.

Insects can be used to suppress different pests of other species, primarily to provide certain organic's production components of crop products. In addition, insects consist of the diet of a significant part of the population, especially in Asia, Africa, Central and South America, as they are an important source of seasonal proteins. Moreover, their use as food products does not directly depend on the income level of the population [2]. Recently, a several of literary sources contain evidence that insects are not only an "emergency resource" to replenish the lack of nutrients in human rations, but also have a pleasant taste, assessed as delicacies, their popularity grows in countries of Western Europe as a new exciting exotic food product [3].

Growth in the material wealth of the population, increased purchasing power and the rapid urbanization of developing countries, primarily Asian countries, create a shift in global demand for food [4]. These factors are the main determinant of increasing global demand for meat products. In high-income countries, meat consumption is expected to increase at $9 \%$ by 2030 , while in China demand growth is expected at $50 \%$, which in turn will increase the need for crops for feeding farm animals [4]. The need for increased production of meat products and rising feed prices in the future will create conditions for the search for alternative sources of protein, among which may be technologies for growing meat in culture media [5], increasing catch and artificially growing sea algae [6], genetically modified vegetable crops and fungi, mini-farm animals [7], which may include insects. 
The aim of the research - to analyze the results of domestic and foreign scientific research in recent years regarding the possibilities of using insects as sources of balanced nutrients for feeding farm animals and biologically active components for the needs of humane and veterinary medicine.

Methods of research: Analytical, theoretical generalization.

Results of research. The statistical results analysis' of the economic state's development of the leading countries world's testify to the urgent need to find alternative sources of protein, alternative to traditional ones. Insects as one of the promising reserves of nutritional protein, fats (including unsaturated omega-3s), vitamins, minerals and biologically active substances are considered by FAO as a possible food security issue since 2010 [3].

The "cold-blooded" insects are efficient converters of organic waste in to biomass with high nutritional value. They do not spend the metabolic energy necessary to maintain a constant body temperature that is higher in mammals than ambient temperature in the growth process. In addition, insects have a high conversion efficiency (conversion efficiency, which is determined by the conversion factor of feed, CFF) compared to other agricultural animals such as poultry, pigs, sheep and cattle.

Due to the limited research results in determining the conversion of feed in to the growth of insect biomass, we give a comparative description of the conversion efficiency for chickens, pigs, cattle and domestic cricket (Acheta domesticus) as insect species example (Table 1)

\section{Efficiency of feed conversion in crickets, in comparison with farm animals}

\begin{tabular}{|l|l|l|l|l|}
\hline 1. Meaning & Crickets [4,9,10] & Chickens [8] & Pigs [8] & Cattle [8] \\
\hline $\begin{array}{l}\text { Feed conversion rate }(1 \mathrm{~kg} \text { of feed: } 1 \mathrm{~kg} \text { of } \\
\text { live weight gain) }\end{array}$ & 1,7 & 2,5 & 5 & 10 \\
\hline Percentage of edible parts of the body & 80 & 55 & 55 & 40 \\
\hline $\begin{array}{l}\text { Nutrition (kilogram per kilogram of mass of } \\
\text { the edible part of the body) }\end{array}$ & 2,1 & 4,5 & 9,1 & 25 \\
\hline
\end{tabular}

According to the specified data, CFF for domestic cricket, chickens and pigs, cattle are 1,$7 ; 2,5 ; 5$ and 10 , respectively. The percentage of edible parts of the body in comparable animals is also significantly different from $40 \%$ in cattle, $55 \%$ in chickens and pigs and up to $80 \%$ in domestic cricket [10].

Comparing the CFFs of traditional agricultural animals and crickets, based on simple calculations, it becomes clear that the consumption of crickets is twice as efficient as the use of chicken meat, 4 times more efficient than pork and 12 times more economically beneficial than consumption of beef.

In addition, insect breeding has less impact on climate change than the traditional livestock sector. Insects that are used as food create less greenhouse gases than most of farm animals. Growing of insects according to available modern technologies does not require the use of large land areas, and the reproduction rates of insects exceed these indicators of other farm animals tenfold. Ultimately, entomophagy raises the standard of living's people on a global scale, primarily economically and socially [11].

Insects breeding can solve the problem of protein deficiency in the future due to population growth, and insect products can make an alternative to traditional food of animal origin.

Due to changing economic conditions, rapid urbanization and demographic change, humanity also faces new issues such as ensuring a proper waste management system and ensuring conditions for economic growth. Although in many developed countries, partial sustainable solutions have already been found and integrated into large recycling companies, most of the solid household waste is expected to increase globally from the current level from 1,3 billion tons per year to 2,2 billion tons in 2025 [12].

In low-income countries, including Ukraine, where modern waste management technologies are not implemented, there is a significant threat of an environmental crisis. The content of organic matter in solid household waste in such countries can reach over $90 \%$. In the countries of East Asia and the Pacific Ocean region, for example, household waste contains $62 \%$ of organic compounds, on average [12]. The lack of infrastructure for solid waste and waste water treatment leads to their generation and accumulation in landfills where, at the best way they are burned. 
Almost a catastrophic environmental situation due to the lack of a technological scheme for the disposal of solid domestic waste has already been established in Ukraine in Lviv region. As a result, the "Solid Waste Management Program in Lviv for 2014-2018" was urgently established in accordance with the Laws of Ukraine "About Waste". The key principles of this program are that "the gap between progressive accumulation of waste and measures aimed to preventing their formation, expansion of utilization, decontamination and disposal, threatens not only the deepening on the environmental crisis, but also on the aggravation of the social situation in general. Hence - the need for further improvement and development taking into account domestic and world experience of the whole legal, normative-methodological and technoeconomic system of waste management, subject to financing of measures at the local and state levels" [13].

Processing of organic waste by insects is a cheap and environmentally safe technology, while byproducts of the food industry, supermarkets, large livestock farms, dumps, etc. can be used as a source of food for some insect species. This approach allows obtaining a biomass of insects with a high-nutritional protein contents.

Utilization of organic waste with fertilizer production can be an economically attractive project aimed to obtaining substances for enhancing the soil fertility in Ukraine, which is substantially impoverished by the proliferation of technical crops and neglected use of ploughlands. The policy of many states in solving this important issue is based either on the utilization of organic emissions or on the possibility of their bioconversion by living organisms for further use in agriculture. The conversion of organic waste into compost by rain or California worms and various microorganisms is a long-known bioorganictechnology [14]. Recently, there were general reports on the use of some insect's species for the organic waste processing on the industrial scale. Among them there are the most promising objects as black soldier fly larvae (Hermetia illucens, BSF), common domestic fly (Musca domestica) [15], and some kinds of flour beetles [16]. The BSF has a particularly interesting candidate for the transformation of organic waste $[4,145]$. Its

larvae can convert spoiled dairy products, poultry and pigs manures, dung of farm livestock into body weight up to $58 \%$ and convert nitrogen and phosphorus of organic waste into an available form by 61 $70 \%$ and $30-50 \%$ respectively [17].

It should be noted that the technology of breeding insect larvae for bioconversion of organic waste on an industrial basis has been firstly introduced in United States and followed spreading to the other country, including China, some EU countries and South Africa. To create our own technologies in other countries, including Ukraine, it is necessary to conduct complex scrutiny of biotic and abiotic factors, to determine optimal growing conditions, taking into account the specificity of each insect species, to investigation the safety possibilities of this process, which is associated with the presence of pathogens, heavy metals and aggressive substances in organic waste and its automatization.

Entomological biotechnology makes it possible to efficiently dispose organic waste for a short period: from 2 to 4 weeks, while reducing the potential risks of environmental pollution. The basis of the developed technology is the metabolic utilization of organic waste, during which bioconversion of waste into ecologically clean products occurs, such as protein-lipid concentrate (yield about $20 \%$ ) and biohumus (yield about $50 \%$ ).

A successful example of bioconversion of organic waste in fodder's protein is the company from the South African Republic "AgriProtein". After investing 11 million \$ from strategic partners for commercialization and globalization, the company has entered a capacity that allows the daily disposal of 40 tons organic's waste with the production of 7 tons of the proteins, 3 tons of the oil and 20 tons of the soil fertilizer. The Bill and Melinda Gates Foundation, is the largest investor in this project, believes that insect breeding should become a lucrative business in a few years, as it solves two major global problems - protein production and the recycling of organic waste. The importance of using environmental biotechnology has the great importance for developing countries.

The cost of producing commercial feed for the livestock's needs globally reach in recent years is $\$ 350$ billion, with a negative tendency to its annual growth, which is equivalent to the cost of the final livestock production. Important protein ingredients for animal feed are the fish and the meat-bone meal as well as soy beans. However, in the European Union, the use of processed animal proteins in animal feed is prohibited by current legislation due to BSE (bovine spongiform encephalopathy). The availability of land suitable for growing soya is limited, fishing of pelagic fodder fish for obtaining feed fishy flour and fat is constantly 
reduced. Thus, the search for alternative sources of animal protein for livestock and aquaculture is an urgent problem and a top priority for ensuring stable development of the industry.

Many studies have found that insects contain about $30-70 \%$ of high quality protein. Table 2 shows the quantitative content of protein and fat in larvae of three insects species compared to fish-bone meal and lowfat soy meal. In insect larvae, slightly less crude protein is contained than in fish-bone meal (57-79\%), but its content is higher compared to defatted soy and meat-bone meal. It should be emphasized that the content of raw fat in the larvae of BSF and yellow mealworm is higher than in meat-bone meal by $15 \%$ and $27 \%$, respectively.

2. Comparison of protein and fat content in insect larvae and livestock feed components

$[3,15]$

\begin{tabular}{|l|l|l|}
\hline Protein source & Crude protein (\%) & Crude fat (\%) \\
\hline $\begin{array}{l}\text { Hermetia illucens } \\
\text { Black soldier fly }\end{array}$ & $35-57$ & 35 \\
\hline $\begin{array}{l}\text { Musca domestica } \\
\text { Ordinary domestic fly }\end{array}$ & $43-68$ & $4-32$ \\
\hline $\begin{array}{l}\text { Tenebrio molitor } \\
\text { Yellow mealworm }\end{array}$ & $44-69$ & $23-47$ \\
\hline Fish-bone meal & $61-77$ & $11-17$ \\
\hline Low-fat soybean meal & $49-56$ & 3 \\
\hline Meat-bone meal & $30-50$ & $13-20$ \\
\hline
\end{tabular}

Proteins derived from insects are readily available for consumption with quality values, similar or even better than meat of fish or soy meal due to the balanced composition of essential amino acids: arginine, lysine and methionine. Experiments with the addition of domestic fly (Musca domestica), BSF larvae (Hermetia illucens), domestic crickets (Gryllus assimilis), yellow mealworm (Tenebrio molitore) and various species of lepidopterous insects led to increasing in average daily gain of rates of chickens and some species of fish in aquaculture [18].

Experiments on the feeding chickens by the yellow mealworm's larvae have led to increasing of the level of vitamin $D$ in the blood, with high content and good bioavailability of calcium [19]. Chicken rations of broilers containing $10-15 \%$ of the beetle's larvae provide an intensive increasing of the live weight and increasing of the slaughter quality of poultry carcasses [20]. Using of the black soldier fly's larvae as an ingredient of protein feed proved to be effective in the cultivation of tilapia, canal catfish and rainbow trout $[3,4]$ without reducing the taste qualities of their meat for consumers.

It was found that the black-soldier fly larvae are a suitable ingredient in the feed for pigs due to the favorable composition of amino acids, lipids and calcium content [21]. However, when balancing rations of pigs, it is necessary to take into account the relative deficiency of essential amino acids: methionine, cysteine and threonine. The best effect in feeding early weaned pigs with diets that replaced the meat and bone meal by $50 \%$ for the dry pre-pupas of the BSF led to increase the average daily growth of pigs in comparison with the control group by $4 \%$, with an improvement in the conversion rates of feed by $9 \%$ [22]. Information about the experiments of results on feeding pigs using insect larvae is limited. In Thailand, when feeding weaning piglets rations with the addition of $10 \%$ of the black soldier fly's larvae, instead of fishmeal was not adversely affected by the growth rates of live weight and the efficiency of the use of feed in all growing periods [23].

Thus, the use of insects as ingredients of animal feeds is a promising direction and can be improved if appropriate technologies are developed that can make the cost of the products as cheap as possible. The main task is to make these products competitive in comparison with traditional protein components of feeds soy meal, meat - bone and fish meal. The basis of such technologies may be the use of organic waste for cultivation insect larvae that are used for the safe and adequate feeding of pigs and poultry. The amino acid profile of the yellow mealworm's larvae, the common housefly and the the black soldier fly, is similar to the composition of soybean meal, but the unsuccessful ratio of methionine to cystine is a definite limiting factor in feeding agricultural animals without adequate correction of the rations [24]. 
Particular attention should be paid to the prospects of using biologically active substances, the source of which are insects of various species, for the needs of light industry, agriculture, humane and veterinary medicine. First of all, unlimited possibilities of application in various spheres of science and practice have already been proved for a substance that is a by-product of insect processing for feeding farm animals is chitin $(8-20 \%$ of the total body weight). The positive effect of chitin on the decreasing cholesterol level in human blood was shown. Chitin acts as active substance for stop bleeding, treating burns and wounds, acting as a hypoallergenic vehicle for other medicinal substances, provides high strength of organic plastic, posses of sorbent properties for wastewater treatment, inhibits pathogenic microflora and soil nematodes thereby increasing yields of grains and legume crops by almost $20 \%$ [18].

Chitosan is derived from chitin, by alkaline deacetylation. Recently, chitosan was given special attention as the substance that solves a lot of issues in the field of veterinary medicine, where is used as a therapeutic agent to stop bleeding, healing of infected wounds, due to the high antimicrobial properties [18].

Antimicrobial peptides are key elements of innate immunity against bacterial and fungal infections. Among a powerful list of such peptides, more than half are found in representatives of the insect class [4]. The action's mechanisms of peptides extracted from the honey bees (Apis mellifera), silkworm (Bombix mori), yellow mealworm (Tenebrio molitor) and larvae of large wax moth (Galleria mellonella) are best described. Inhibitors of insects' metalloproteinases and antimicrobial peptides of large wax moth can become promising components in the rational development of new drugs, since the combination of antibiotics with inhibitors of proteolytic enzymes leads to a synergistic therapeutic effect [25].

The properties of certain biologically active substances isolated from the body of silkworm pupaes (angiotensin-converting enzyme inhibitors) open up a prospects for the treatment of human hypertension and drug dependence, active research is being conducted on the possibility of using endopeptidase isolated from Tenebrio molitor larvae in celiac disease treatment regimes. Apitoxin of honey bees, the most well-known therapeutic agent of inflammatory and autoimmune diseases, including disseminated sclerosis, arthritis, rheumatism, neurological and dermatological diseases.

Summarizing the analysis of the main opportunities and strategies for industrial insect breeding for agriculture, light industry, human and veterinary medicine, it should be noted that along with indisputable advantages, there are a number of unresolved issues that require long-term scientific research, not only in assessing economic profits, but also in calculating financial, market, environmental and ethical risks.

\section{Conclusions}

The very important and urgent problem of a global scale, including Ukraine, is the development and implementation of the industrial entomology, modern technologies to provide mass breeding of insects, the production of protein and other biologically active safe substances. The creation of a new industrial entomology sector for food and animals feed is possible only on the basis of effective cooperation between state bodies, industry and science specialists.

\section{References}

1. Polishchuk V.P. Wax Moth / V.P.Polishchuk, O.V.Korbut // Pasika.-2014.- T.4.- №252.-P.23-27.

2. Entomophagy: A key to space agriculture/ N. Katayama,Y. Ishikawa , M.Takaoki [et al.] // Adv. Space Res. -2008.- V. 41. - P. 701-705.

3. A comprehensive look at the possibilities of edible insects as food in europe - a review/J. Mlcek, J.Rop, M.Borkovcova [et al.] // Pol. J. Food Nutr. Sci. - 2014. — V. 64. - N 3. - P. 147-157.

4. Van Huis A. Insects as food in sub-Saharan Africa/A. Van Huis / Insect Science and its Application. 2003. - V. 23. - №3. - P. 163-185.

5. Fayaz B. Z. Prospectus of cultured meat-advancing meat alternatives/

B.Z.Fayaz, H.Fayaz // J. Food Sci. Technol. — 2011. - V. 48. - P.125-140.

6. Fleurence J. Seaweed proteins: biochemical, nutritional aspects and potential uses/ J. Fleurence// Trends Food Sci. Technol.—1999. —V. 10. — P. 25-28.

7. Paoletti M.G. Ecological Implications of Minilivestock: Potential of Insects, Rodents, Frogs and Snails/ M.G.Paoletti // Enfield. — 2010. — NH: Science. -648p. 
8. Smil V. Worldwide transformation of diets, burdens of meat production and opportunities for novel food proteins/ V.Smil// Enzyme Microb. Technol. — 2002. - V.30. - P.305-311.

9. House cricket small-scale farming/ A.Collavo, R.H.Glew, Y.S.Huang [et al.] // See Ref. — 2005. —V.115. - P. 519-544.

10. Nakagaki B.J. Comparison of diets for mass-rearing Acheta domesticus (Orthoptera: Gryllidae) as a novelty food, and comparison of food conversion efficiency with values reported for livestock / B.J.Nakagaki, G.R. de Foliart// J. Econ. Entomol. — 1991. —V.84. - P.891-896.

11. Insects as food and feed/P.J.Anankware, K.O.Fening, E.Osekre, D.Obeng-Ofori // International Journal of Agricultural Research and Review. — 2015. — V. 3. —№1. — P. 143-151.

12. Hoornweg $D$. What a west: a global rewiew of solid waste management/ D.Hoornweg, P.BhadaTata/— 2012. - World Bank.: Washington, DC 20433, USA. — №15. - 100p.

13. The Law of Ukraine "About Waste" of April 7, 2015 N 287-VIII.-Kyiv.- LTD "Raindo" .- 2015.- 36s.

14. Potentiality of earthworms for waste management and in other uses: a review/ S.Sharma, K.Pradhan, S.Satya, P.Vasudevan //J. Am. Sci. — 2005. — V.1. — №1. — P. 4-16.

15. Housefly larvae meal grown on municipal organic waste as a source of protein in poultry diets/ E.Ocio, R.Vinaras, J.M.Rey// Anim. Feed Sci. Technol. 1979. - V. 4. - P. 227-231.

16. Despins J. L. Feeding behavior and growth of broiler chicks fed larvae of the Darkling beetle, Alphitobius diaperinus/ J.L.Despins, R.C.Axtell // Poult. Sci. —1995. — V. 74. — P. 331-336.

17. Development of black soldier fly Diptera: Stratiomyielae) larvae fed dairy manure/H.M.Myerss, J.K.Tomberlin, B.D.Lambert, D.Kattes// Environ. Entomol. - 2008. - V. 37. - P. 11- 15.

18. Biologically active substances of edible insects and their use in agriculture, veterinary and human medicine - a review/ J.Mlcek, M.Borkovcova, M.Bednarova /Journal of Central European Agriculture. —2014. - V. 15. - №4. - P. 225-237.

19. Increasing the calcium content of mealworms (Tenebrio molitor) to improve their nutritional value for bone mineralization of growing chicks/ K.C.Klasing, P.Thacker, M.A.Lopez, C.C.Calvert //Journal of Zoo and Wildlife Medicine. -2000. - V. 31. - P 512-517.

20. Utilization of house fly-maggots, a feed supplement in the production of broiler chickens/J. Hwangbo, E.C.Hong,A.Jang, H.K. Kang [et al.] //Journal of Environmental Biology. — 2009. —V. 30. — P. 609—614.

21. State of the art on use of insects as animal feed /H.P.S. Makkar, G.Tran,V. Heuzé, P.Ankers //Anim. Feed Sci. - 2014. - V.197. - P. 1-33.

22. Hermetia illucens larvae meal as a supplement for swine/G.L. Newton, C.V. Booram, R.W.Barker, O.M.Hale [et al.] // J. Anim. Sci. — 1977. —V. 44. — P.395—400.

23. Viroje $W$. Effects of fly larval meal grown on pig manure as asource of protein in early weaned pig diets /W.Viroje, S.Malin // Thurakit Ahan Sat. - 1989. - V. 6. - P. 25-31.

24. Veldkamp T. Insects: a protein-rich feed ingredient in pig and poultry diets /T.Veldkamp, G.Bosch // Published March. — 2015. —V5. —№2. -P.45-50.

25. Vilcinskas $A$. Anti-infective therapeutics from the lepidopteran model host Galleria mellonella /A.Vilcinskas //Current Pharmaceutical Design. -2011. — V. 17. — P. 1240-1245. 